\title{
死体腎提供者拡大への糸口を求めて 一献眼率日本一の静岡県小山町に学ぶー
}

\author{
内出幸美泉田 スミ子 泉 ハシメ 佐々木 キヨ \\ 荒隆 一* 木川田 典弥** \\ 地ノ森クリニック・医療相談室・看護部 埼仁クリニック* 岩手県立大船渡病院第 3 外科** \\ (平成 1 年 5 月 10 日受付, 同年 8 月 8 日受理)
}

vey words: 死体腎提供者, ライオンズクラブ, 日本人の心情, アフターケア, 啓蒙活動

〈要旨〉

日本での腎移植普及を考える場合, 最大の課題は死体腎提供者の確保であると思われる. そこで著者らは, 献眼登 觮率・献眼率日本一である静岡県小山町を訪れ，午の独創的と思われる活動方法を調査した。

その活動の中心はライオンズクラブである. この小山ライオンズクラブは 1970 年より献眼運動を推進している. 全 四民への熱心な啓蒙活動, 献眼に際しての, 手術医への連絡, 交通の手配から献眼者の葬儀まで全会員を揚げての誠 急ある活動, 献眼者の遺族への感謝状の伝達式や様々な催し物を通して後々まで遺族との心の触れ合いを前提とし, 町民との交流を大切にしている.

その結果, 町全体に献眼の思想が行き渡り, 多少の抵抗感はありながらも献眼するのが当り前へと云う雾囲気につ つまれている。

著者らは, 死体腎の提供者不足は多くの日本人が遺体に原始的な執着心を持っており, 炎の独特の死生観・倫理観・ 心情等があることが最大の要因と考えている. このような日本人の心情は, 社会が進歩したからと云ってそう急激に 変わるものではないと思われるが, 著者らには日本人のこの心情をどのように変えてゆくかと云うことが死体腎提供 者拡大への最大の課題であると思われる. 今回, 静岡県小山町の調査をした結果, 日本人の心情などは, 国民に対す る熱心な限りない推進運動と啓蒙活動によって少しずつ変化し, 欧米並みの意識レベルまで達するとの確信を得た. それらの活動の重要点は, まず地域単位の推進母体の体制確立とその組織の明確化, そして推進員の行動力と誠意あ るアフターケアが必須条件であると考えられた。

An opportunity to increase kidney donors: lesson learned in Oyama-cho, Shizuoka where the percentage of eye donations is the highest in Japan

Yukimi Uchide, Sumiko Izumida, Hashime Izumi, Kiyo Sasaki, Ryuichi Ara, MD. ${ }^{*}$, Noriya Kikawada, MD.** Jinomori Clinic ; Saijin Clinic* ; 3rd Division of Surgery, Iwate Prefectural Hospital of Ofunato**

The primary problem in furthering kidney transplantation in Japan in that of secuing kidney donors. Thus, upon visiting Oyama-cho, Shizuoka, which has the highest number of eye donor registrations and the highest percentage of eye donations in Japan, we investigated the creative activities underway in this town.

The activities in the town center on the Lion's Club. The Oyama Lion's Club has been promoting an eye donation campaign since 1970, which includes, in addition to enthusiastic education in the town, notifying surgeons of offers of eyes, arrangement for transportation, funerals for eye donors, conveyance of acknowledgements to the bereaved families and maintenance of continued communicaton with them. Thus the club places importance on communication with the town's people.

Consequently, the concept of eye donation has been spread throughout the town, where many are inclined to

内出 幸美 地ノ森クリニック

₹ 022 大船渡市船渡町字地ノ森 36-7（0192-27-1721） think it natural to donate eyes, although there is some reluctance. 
We think that the shortage of kidney donors in Japan can be ascribed mostly to Japanese views on life, death and morality, as well as sentiments including a traditional reverence for the dead. This sentiment of the Japanese does not seem to be changing. We believe that the primary problem in increasing kidney donors lies in changing this Japanese value. Having carried out a survey, in Oyama-cho, we were convinced that such values can be changed gradually, until they are similar to those in Europe and America by enthusiastically promoting new ideas and educating the people. Such activities should be directed to establishing community promotional systems and sincere aftercare.

\section{緒言}

日本の腎移植の現況を記載する。全透析患者数は 80553 人であり，この 80000 人を越える透析患者のうち 8334 人の患者が害際に死体腎移植登録を行っている.わ が国において，腎移植は，1964 年に初めて施行されて以 来 1986 年末までに 4620 回，最近徐々に増えてきている とはいえ年間 500 回にすぎない．欧米に比べて極めて腎 移植患者の割合が低いことが分かる(図 1 )。また，日本 の腎移植は生体腎移植が主体で $75.3 \%$ 占めている(図 2). 前述したように, 腎移植において日本と欧米を比べ た場合，大きな違いは，日本は透析患者数に対して移植 患者数が極めて少ないこと，死体腎移植が主流の欧米に 比べ日本は生体腎移植が主流であると云う 2 点である。

この違いがそのまま腎移植の普及の差につながつている と云える。

では，何故，欧米諸国に比べて日本では腎移植が普及 しないのであろうか.日本でもこの 10 年間に腎移植普及 のために，医学的・社会的諸条件が整備改善された。し かし，腎提供者不足は依然として最大の問題である。

そこで著者らは, 死体腎提供者拡大への系口を求めて, 献眼率・献眼登録率とも日本一である静岡県小山町を訪 れ，その独創的とも思われる活動方法を調查した。

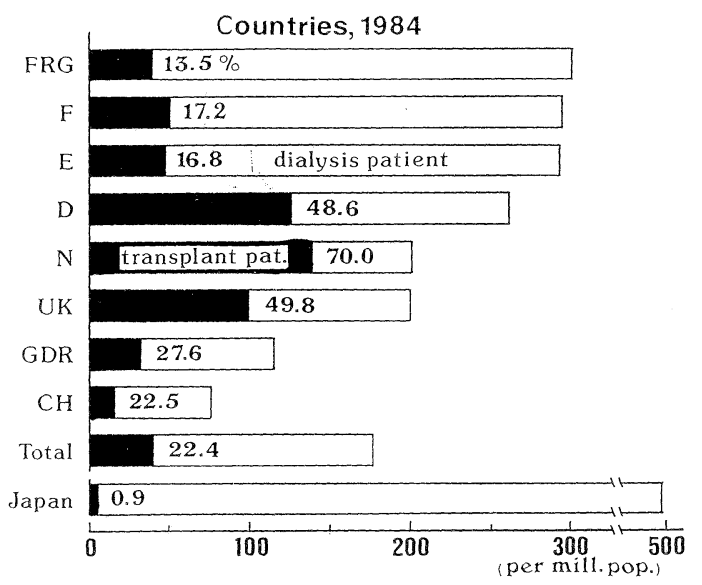

図 1 Contribution of transplantation in selected countries, 1984

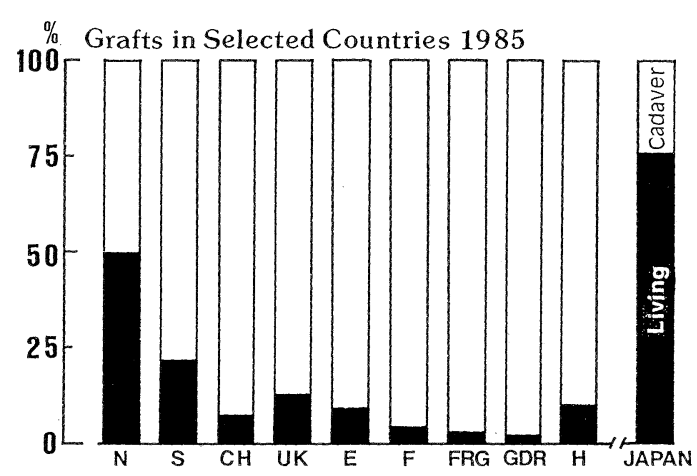

図 2 Frequency distribution living donor and cadaver

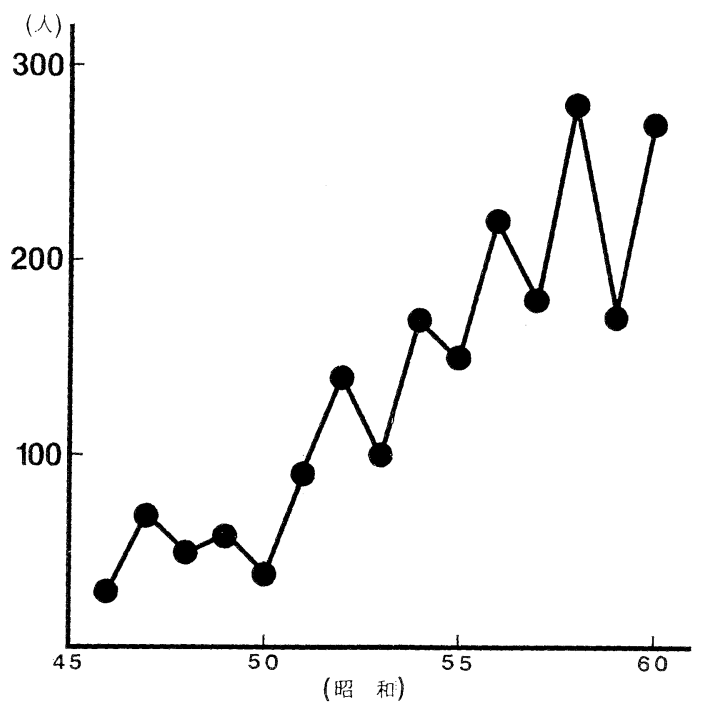

図 3 The people of eye donations is number in Oyama-cho

\section{調查内容}

小山町の 1988 年 11 月現在の献眼者数は 267 人, 即ち 献眼数 534 個となり, その数は全国の献眼者数 2000 人の $1 \%$ にもなる。また, 同町の献眼登録者数は 2766 人で町 民 10 人に 1 人の割合となっている（図 3 ）。 
表 1 活動内容

1. 全町民への熱心な宣伝活動
2. 会員の誠意ある姿勢
・献眼までのお手伝い
・扮通夜, 告別式
3. 献眼後の町民との心の交流
$\quad$ ・厚生大臣感謝状伝達式
・アイバンクの夕べ
・献眼者合同慰霊祭
4. その他
$\quad$ ・報道
$\quad$ ・行政の協力

その献眼運動の中心はライオンズクラブであり，同ク ラブの献眼運動は，結成 5 周年を機に 1970 年「目の不自 日な人々に希望の光を」と始められた。 そして会員及び その家族全員による献眼登録によって献眼運動に初めて 灯がともされた。当初はなかなか理解が得られず, 会員 の親戚や知人, 職域を頼っての地道な活動が続けられた. その結果徐々に献眼者も増え, 全国一を誇るに至り，そ の功績によって全世界のライオンズクラブの最高栄誉賞 と云われる「トップテンクラブ奉仕事業賞」を昨年受賞 したとのことである。

手さぐりの奉仕からこのような大きな奉仕運動に育っ てきた理由に，

1 ）全町民への熱心な宣伝活動が掲げられる. 町内 50 区の区長との会合により“ライオンズクラブ友の会”を 結成し各区長から区民への輪が広がってきた。また，婦 人会・青年団など各種団体との懇談会, 陸上自衛隊富士 学校への宣伝と登録推進をはかろうと全会員が必死で啓 蒙活動を行った。

2 ）全会員をあげての誠意ある姿勢が掲げられる。献 眼の際には, 遺族への献眼のお願い, 手術医への連絡及 び出迎えから献眼の終了までの立ち合いを必ずする。こ れらの組織化が確立されているので無駄がなく, 整然と 事が運ばれると云うことである。そしてライオンズクラ ブではお通夜・告別式へ全会員の参列方を要請している. この告別式には，ライオンズクラブのアイバンク委員長 による感謝状の朗読, 献眼に対する扔礼，そして参列者 に献眼登録についての宣伝も兼ねての挨拶がある，その 中でも遺族の感激と参列者へ与える深い感銘は「献眼さ れた角膜が○歳と○歳の方に無事移植され光が与えられ ました.」との報告がされた時であり，同時に献眼式典の クライマックスでもある。遺族は，このような話をされ ることにより「ああ, 提供を承諾して本当に良かった.」 と献眼の行為を肯定できたとのことである。このように 告別式での挨拶が大変大きな宣伝の役割を果たしている
ことが分かる．会員にとっては手術医師の出迎え，案内 に始まり，通夜・告別式と多忙な 3 日間であるが，40人 足らずの会員は葬式屋か!? と陰口をたたかれた時期も あったにしても, 行動力に富み, 生き生きと誇りをもっ て奉仕している姿が無言の宣伝となり，またそれを自負 しているとのことである.

3 ）この献眼運動の大きな柱であるのが, 献眼後の会 員と遺族・町民との心の交流である.ライオンズクラブ では, 献眼者をその都度厚生大臣に上申し得られた感謝 状・記念品の伝達式を行い，また絶えず献眼された方々 に対して尊敬と感謝の気持ちを伝えるため, 千有余名の 関係者を招いての「アイバンクの夕心゙」を開催したり， 献眼者百人・二百人合同慰霊祭を実施するなどしている。 このようにライオンズクラブでは，献眼時のみでなく長 い感謝の気持ちを表し, 遺族・町民の心を大切にしてい ることが非常に特徴的であると思われた。

このような献眼運動, すなわち一つ一つの啓蒙運動の 積み重ねの結果が, 町全体に献眼の思想が行き渡ったと 思われた，遺族の方々も「亡くなったら目をとられるの が普通になった」，「最初はなんとなくいやだなアと思っ たが皆がやっているんだから…」, 「葬式の際，移植者の 話をされ本当にあげて良かったと思った。私もそれ以来 献眼登録をした」等々と町の方々が話していることから もうかがえる。このように，多少の抵抗感はありながら も，献眼登録や献眼することが当り前と云う雾囲気が既 にできあがっている。

\section{考察及び結語}

著者らは, 死体腎の提供者不足は多くの日本人が遺体 に原始的な執着心を持っており，その独特の死生観・倫 理観・心情等があるのが最大の要因と考えている。この ような日本人の心情は, 社会が進歩したからと云ってそ う急激に変わるものではないと思われるが, 著者らは日 本人のこの心情をどのように変えてゆくかと云うこと が, 死体腎提供者拡大への最大の課題であると考えてい る.

今回, 静岡県小山町の調查をした結果, 日本人の心情 等は, 国民に対する熱心な限りない推進運動と啓蒙活動 によって少しずつ変化し欧米並みの意識レベルまで達す るとの確信を得た. それらの活動の重要点は, まず地域 単位の推進母体の体制確立とその組織の明確化であり, 推進員の行動力と誠意あるアフターケアが必須条件であ ると考えられた。

なお, 本論文の要旨は第 22 回腎移植臨床検討会において発 表した. 調査にご協力いただいた小山ライオンズクラブの皆 さん，ご遺族の方々に深謝致します。 


\section{文献}

1) Figures from combined report on regular dialysis and transplantation in Europe. Proc EDTA, 1985

2）日本移植学会：腎移植臨床登録集計報告. 移植 22 ： 561, 1987

3) 小高通夫：わが国の慢性透析療法の現況 (1987 年 12
月 31 日現在), 透析会誌, 1988

4）木川田典弥, 内出幸美, 佐々木キヨ, 泉ハシメ：The Problem of Transplantation in Buddhist Thinking. 岩手県病医会誌 $28: 76$-80, 1988

5）アイバンク推進委員会：小山 LC 方式運動のすすめ 方.アイバンク運動の手引 : 6-13, 1977 